tràng là các yếu tố ảnh hưởng đến mức độ sẵn sàng chi trả (4).

Đánh giá chung về khả năng chi trả. Kết quả nghiên cứu ghi nhận có $72,2 \%$ đối tượng tham gia khảo sát cho rằng số tiền chi trả cho các dịch vụ của gói khám tầm soát và phát hiện sớm ung thư vú (theo giá niêm yết) là phù hợp. Có $38,3 \%$ cho rằng số tiền chi trả cho các chỉ định khác khi cần thiết ngoài gói khám tầm soát ung thư cơ bản (theo giá niêm yết) là phù hợp và $84,2 \%$ đồng ý cho rằng việc khám và tầm soát sớm có thể hạn chế nguy cơ bị mắc bệnh ung thư vú.

\section{KẾT LUÂN}

Khi giá niêm yết cho toàn bộ 4 dịch vụ của gói khám cơ bản là 820.000 đồng thì có $87,1 \%$ đồng ý sẵn sàng chi trả; nếu gói khám tăng giá $10 \%$ thì có $43,3 \%$ đồng ý chi trả; nếu gói khám tăng giá $20 \%$ thì có $18,8 \%$ đồng ý chi trả. Bên cạnh đó, nếu gói khám giảm giá $10 \%$ thì có $83,8 \%$ đồng ý chi trả; nếu gói khám giảm giá $20 \%$ thì có $92,1 \%$ đồng ý chi trả.

Khả năng chi trả theo giá niêm yết cho từng dịch vụ riêng lẻ của gói "Khám tầm soát Ung thư vú" thì lần lượt $89,2 \%, 85,4 \%, 85 \%$ người trả lời có khả năng chi trả để khám tầm soát ung thư vú, Siêu âm Doppler màu mạch máu [tuyến vú - nách] và chụp Xquang tuyến vú [1 bên 2 phim].

Kết quả nghiên cứu ghi nhận có $72,2 \%$ đối tượng tham gia khảo sát cho rằng số tiền chi trả cho các dịch vụ của gói khám tầm soát và phát hiện sớm ung thư vú (theo giá niêm yết) là phù hợp. Có $38,3 \%$ cho rằng số tiền chi trả cho các chỉ định khác khi cần thiết ngoài gói khám tầm soát ung thư cơ bản (theo giá niêm yết) là phù hợp và $84,2 \%$ đồng ý cho rằng việc khám và tầm soát sớm có thể hạn chế nguy cơ bị mắc bệnh ung thư vú.

\section{TÀI LIÊU THAM KHẢO}

1. Bộ y tế (2016), Báo cáo chung tổng quan ngành $y$ tể JAHR;

2. Bv Ung Bướu, Quyết định số 1232/QĐ-BVUB ngày $29 / 05 / 2018$ vế giá gói khám tư vấn và phát hiên sớm ung thư vú tại Khoa Tâm soát Ung thư, Bv Ung bướuTP.HCM;

3. Wenchi Liang, William F. Lawrence, Caroline B. Burnett, Yi-Ting Hwang, Matthew Freedman, Bruce J. Trock, Jeanne S. Mandelblatt, and Marc E. Lippman (2003), Acceptability of diagnostic tests for breast cancer, Breast Cancer Research and Treatment 79:199-206

4. Hollinghurst S., Banks J., Bigwood L. và cộng sư. (2016). Using willingness-to- pay to establish patient preferences for cancer testing in primary care. BMC Med Inform Decis Mak, 16(1),105

\title{
NHU CẦU ĐIỀU TRI BÊNNH VIÊM LợI TRÊN PHỤ NŨ CÓ THAI TẠI KHOA SẢN BỆNH VIỆN BẠCH MAI, NĂM 2019-2020
}

\author{
Phan Huy Hoàng*, Hoàng Bảo Duy*, \\ Hà Ngọc Chiều*, Trịnh Thị Thái Hà*, Lê Hưng**
}

\section{TÓM TĂT}

Muc tiêu: Xác đinh nhu cầu điều tri viêm lợi trên phụ nữ có thai tại khoa sản bệnh viện Bach Mai - Hà Nội năm 2019-2020. Phương pháp nghiên cứu: mô tả cắt ngang. Kết quả: phụ nữ mang thai chủ yếu có nhu câu điều trị viêm lợi mă số 2 . Phụ nữ mang thai 3 tháng đâuu chỉ có chỉ số nhu cầu điều trị mã số 1 và mã số 2,3 tháng giữa và 3 tháng cuối chỉ có mã số 2 và mã số 3. CPITN mã số 3 nhóm răng phía trước chiếm $0,9 \%$, CPITN mã số 3 nhóm răng phía sau 9,2\%. Kết luận: Hầu hết phụ nữ mang thai có nhu câuu hướng dẫn vệ sinh răng miệng, lấy cao răng và làm nhẵn mặt chẩn răng, loại trừ cặn bám răng. Cần

*Viện Đào tạo Răng Hàm Mặt, Trường Đại học Y Hà Nội **Bênh viền Đa khoa Đông Đa

Chịu trách nhiệm chính: Phan Huy Hoàng

Email: Nhasixman@gmail.com

Ngày nhận bài: 25.01.2021

Ngày phản biên khoa học: 8.3.2021

Ngày duyệt bài: 22.3.2021 tăng cường công tác chăm sóc sức khoẻ răng miệng cho phụ nữ có thai để kiểm soát bệnh lý và loại bỏ các nguy cơ gây bệnh răng miệng tiềm ẩn có thể phát sinh trong suốt thai kỳ.

Tứ khoá: Nhu cầu điêu trị, viêm lợi, phụ nữ có thai.

\section{SUMMARY}

TREATMENT OF GINGIVITIS IN PREGNANT WOMEN AT AT THE OBSTETRICS OF BACH MAI HOSPITAL, 2019-2020

Objectives: Determining the need for gingivitis treatment in pregnant women at the Obstetrics Department of Bach Mai Hospital - Hanoi in 20192020. Research method: cross-sectional description. Results: Mainly, pregnant women need No.2 gingivitis treatment. Women who are pregnant in the first 3 months have only the treatment demand of No.1 and No.2, the middle 3 months and the last 3 months only No.2 and No.3. CPITN, No.3, groups of anterior teeth accounted for $0.9 \%$, of posterior teeth $9.2 \%$. Conclusion: Most pregnant women need instructions on oral hygiene, the method to remove 
tartar and smooth the root surface, eliminate tooth deposits. It is required to strengthen oral health care for pregnant women to control the disease and eliminate the potential oral health risks that may arise during pregnancy.

Keywords; Treatment needs, gingivitis, pregnant women.

\section{I. ĐĂT VẤN ĐỀ}

Sức khỏe mô nha chu ở phụ nữ mang thai đã được cộng đồng quan tâm và tìm hiểu từ nhiều năm của thế kỷ trước. Các nghiên cứu đã tập trung tìm hiểu về mối liên quan giữa bệnh quanh răng ở phụ nữ mang thai với nguy cơ sinh non nhe cân thiếu tháng. Tại vì ổ viêm nha chu là một tổ hợp chứa nhiều vi khuẩn yếm khí, vi khuẩn gram âm, mô nha chu viêm sản sinh ra một lượng lớn cytokin, chủ yếu là interleukin 1 beta (IL-1ß), IL-6, Prostaglandin E2 và yễu tố gây hoại tử u - a (TNF-a), những hoá chất trung gian này có thể lan truyền qua màng nhau thai, gây sinh con nhe cân [1]. Do đó, phư nữ khi mang thai, không chỉ cần quan tâm đến chế độ dinh dưỡng, chăm sóc cho thai nhi, mà còn cần chú ý giữ vệ sinh răng miệng cho thật tốt để bảo đảm sức khỏe cho cả me và con.

Viêm lợi là môt bênh lý phổ biến trong nhóm bệnh quanh răng, nguyên nhân chủ yếu là do tình trạng vệ sinh răng miệng không tốt. Ở việt Nam hầu hết phụ nữ vẫn chưa ý thức đầy đủ về việc vệ sinh răng miệng trước và trong quá trình mang thai. Nhiều thai phụ bị viêm lợi nặng trong quá trình mang thai nhưng không đi điều trị vì sơ ảnh hưởng đến thai nhi. Xuất phát từ tình hình thực tế đó, chúng tôi tiến hành nghiên cứu nhằm mục đích: "Xác định nhu cầu điều trị viêm lợi trên phụ nữ có thai tại khoa sản bệnh viện Bạch Mai - Hà Nội năm 2019-2020"

\section{II. ĐỐI TƯợNG VÀ PHƯƠNG PHÁP NGHIÊN CỨU \\ 2.1. Đối tượng nghiên cứu}

2.1.1. Tiêu chuẩn lựa chọn

- Phụ nữ mang thai có sức khỏe bình thường

- Tự nguyện và đồng ý tham gia nghiên cứu.

\subsubsection{Tiêu chuẩn loại trừ}

- Đối tượng có nguy cở thai kỳ cao: bệnh tiểu đường, cao huyết áp thai kỳ, tiền sử sảy thai nhiều lần, có bệnh toàn thân khác đi kèm, đang sử dụng kháng sinh, đa thai.

- Không đồng ý tham gia nghiên cứu.

\subsection{Phương pháp nghiên cứu} ngang

- Thiết kế nghiên cứu: nghiên cứu mô tả cắt

$$
\text { - Cõ mẫu: }
$$

Áp dụng công thức: $n=Z_{1-\alpha / 2}^{2} \frac{p(1-p)}{d^{2}}$
Trong đó: $\mathrm{n}:$ Cõ̃ mẫu

p: đây là một nghiên cứu đánh giá đặc điểm lâm sàng và xác định nhu cầu điều trị viểm lợi ở phụ nữ mang thai, vì vậy chúng tôi chọn $\mathrm{p}$ là tỷ lệ viêm lợi ở phụ nữ mang thai trong một nghiên cứu tại Brazil $(p=0,844)[2]$

d: Độ chính xác tuyệt đối (chọn $d=0,7$ )

$Z^{2}(1-a / 2)$ : hệ số tin cậy, với mức ý nghĩa thống kê $\alpha=0,05$, tương ứng với độ tin cậy là $95 \%$ thì $\mathrm{Z}_{(1-\mathrm{a} / 2)}=1,96$

Dựa vào công thức trên chúng tôi tính được $n=103$, thực tế chúng tôi đã khám và tư vấn cho 110 phụ nữ mang thai.

\subsection{Các bước tiến hành nghiên cứu}

\subsubsection{Dụng cụ thu thập số liệu}

- Bộ khay khám nha khoa thông thường gồm gương, gắp, thám châm

- Sonde nha chu của WHO

- Phiếu khám

- Các dụng cụ sát trùng: bông, cồn, găng tay.

\subsubsection{Phương pháp thu thập số liệu}

- Liên hệ với ban lãnh đạo khoa Sản và phòng Kế hoạch tổng hợp bệnh viện Bạch Mai.

- Các bệnh nhân đến khám tại khoa Sản bệnh viện Bạch Mai được khám và tư vấn về tình trạng nha chu theo mẫu.

- Cách khám:

+ Phỏng vấn bệnh nhân để thu thập các thông tin về đặc trưng cá nhân và các triệu chứng cơ năng.

+ Đối tượng được khám đánh giá và ghi nhận chỉ số nhu cầu điểu trị quanh răng cộng đồng CPITN: Commurity periodontal index of treatment needs (Ainamo-1982). Mỗi cung hàm được chia làm 3 đoạn gọi là đoạn lục phân (sextant). Mỗi người có 6 sextant. Mổi sextant khám 1 răng đai diện $(16,26,36,46,11,31)$. Chỉ số CPITN của mối người là chỉ số của sextant cao nhất.

\section{Bảng 2.1. Chỉ số nhu cầu điều trị CPITN}

\begin{tabular}{|c|c|c|}
\hline Mã số & Tình trạng & Nhu cầu điều trị \\
\hline 0 & Bình thường & Không cần điều trị \\
\hline 1 & Chảy máu lợi & Hướng dẫn VSRM \\
\hline 2 & Cao răng & $\begin{array}{c}\text { Hướng dâ̂n VSRM + lây } \\
\text { cao răng }\end{array}$ \\
\hline 3 & $\begin{array}{c}\text { Túi nông } \\
<5,5 \mathrm{~mm}\end{array}$ & $\begin{array}{c}\text { Hướng dấn VSRM + lây } \\
\text { cao răng }\end{array}$ \\
\hline 4 & $\begin{array}{c}\text { Túi sâu } \geq \\
5,5 \mathrm{~mm}\end{array}$ & $\begin{array}{c}\text { Hướng dâ̂n VSRM+lấy cao } \\
\text { răng + điêuu trị chuyên sâu }\end{array}$ \\
\hline
\end{tabular}

Phân loai nhu cầu điều tri: bênh nhân được phân loai các mức độ: nhe, trung bình, nặng

- Tốt (mã số 0): không cần điêu trị gì tương ứng với mã 0 CPITN

- Nhẹ (mã số 1): Hướng dẫn vệ sinh răng miệng - tướng ứng với mã 1 CPITN 
- Trung bình (mã số 2): hướng dẫn vệ sinh răng miệng, lấy cao răng và làm nhẵn mặt chân răng, loại trừ cặn bám răng, sửa lại các sai sót trong hàn răng, chụp răng - tương ứng với mã số 2 và 3 CPITN

- Nặng (mã số 3): điều trị phức hợp lấy cao răng và làm nhẵn mặt chân răng, nạo mổ có gây tê phẫu thuât - tương ứng với mã 4 CPITN.

2.4. Xử lý số liệu. Nhập dữ liệu bằng phần mềm Epi-data. Xử lý, phẩn tích số liệu bằng phần mềm SPSS 20.0 và một số thuật toán thống kê y học khác.

\subsection{Biện pháp hạn chế sai số}

- Đối tượng nghiên cứu được chọn theo đúng tiêu chuẩn và chỉ tiến hành khi đối tượng hợp tác tốt.

- Phiếu khám được xây dựng theo mục tiêu, dễ thu thập thông tin.

- Nhập số liệu và xử lý số liệu được tiến hành hai lần để đối chiếu kết quả.

2.6. Đạo đức trong nghiên cứu. Nghiên cứu chỉ tiển hành khi được sự đồng ý của Ban lãnh đạo khoa Sản và Bệnh viện Bạch Mai. Mọi thông tin liên quan đến đối tượng nghiên cứu được giữ bí mật, các số liệu thu thập được chỉ sử dụng vào mục đích nghiên cứu. Đối tượng tham gia nghiên cứu hoàn toàn tự nguyên sau khi được thông báo về mục đích của nghiên cứu, đối tượng có quyền không tiếp tục tham gia nghiên cứu bất kỳ lúc nào nếu muốn. Quá trình khám đảm bảo vô khuẩn, phòng chống lây nhiễm chéo. Tất cả các đối tượng tham gia nghiên cứu đều được tư vấn vệ sinh răng miệng.

\section{KẾT QUẢ NGHIÊN CứU}

Trong nghiên cứu này, phu nữ mang thai ở độ tuổi 20-29 chiếm tỷ lê $51,8 \%$, từ $30-39$ chiếm $36,3 \%$ và từ 40 tuổi trở lên chiếm $11,8 \%$. Phụ nữ trẻ nhất mang thai là 21 tuổi và phụ nữ lớn tuổi nhất mang thai là 45 tuổi. Có $18,2 \%$ phụ nữ mang thai trong 3 tháng đâu, $43,6 \%$ trong $3-$ 6 tháng và 38,2\% trên 6 tháng. Có $37,3 \%$ phụ nữ mang thai lần $1,43,6 \%$ phụ nữ mang thai lần 2 và $19,1 \%$ phụ nữ mang thai từ 3 lần trở lên. 100\% phụ nữ mang thai bị viêm lợi.

Bảng 3.1. Phân bố nhu cầu điều trị theo tuổi của phụ nữ mang thai

\begin{tabular}{|c|c|c|c|c|c|c|c|c|}
\hline \multirow{2}{*}{$\begin{array}{l}\text { Mã số } \\
\text { Tuổi phưnữ } \\
\text { mang thai }\end{array}$} & \multicolumn{2}{|c|}{ Mã số 0} & \multicolumn{2}{|c|}{ Mã số 1} & \multicolumn{2}{|c|}{ Mã số 2} & \multicolumn{2}{|c|}{ Mã số 3} \\
\hline & $\begin{array}{c}\text { Số } \\
\text { lượng }\end{array}$ & $\begin{array}{l}\text { Tỷ lề } \\
(\%)\end{array}$ & $\begin{array}{c}\text { Số } \\
\text { lượng }\end{array}$ & $\begin{array}{l}\text { Tỷ lệ } \\
(\%)\end{array}$ & $\begin{array}{c}\text { Số } \\
\text { lượng }\end{array}$ & $\begin{array}{l}\text { Tỷ lệ } \\
(\%)\end{array}$ & $\begin{array}{c}\text { Số } \\
\text { lượng }\end{array}$ & $\begin{array}{l}\text { Tỷ lệ } \\
(\%)\end{array}$ \\
\hline $20-29$ tuối & 2 & 1,8 & 5 & 4,6 & 47 & 42,7 & 4 & 3,6 \\
\hline $30-39$ tuổi & 0 & 0,0 & 3 & 2,7 & 28 & 25,5 & 5 & 4,6 \\
\hline$>40$ tuổi & 0 & 0,0 & 1 & 0,9 & 15 & 13,6 & 0 & 0 \\
\hline Tổng & 2 & 1,8 & 9 & 8,2 & 90 & 81,8 & 9 & 7,4 \\
\hline
\end{tabular}

Nhân xét: Nhóm phụ nữ mang thai có độ tuối 20-29 tuối có đủ 4 mức nhu cầu điều trị 0-3, trong đó mã số 2 chiếm tỉ lệ cao nhất $42,7 \%$, tiếp theo là mã số 1 với tỉ lệ $4,6 \%$, mã số $3(3,6 \%)$ và mã số $0(1,8 \%)$. Nhóm phụ nữ mang thai có độ tuổi 30-39 và > 40 tuổi không có nhu cầu điều trị mức 0 . Sự khác biệt giữa các nhóm không có ý nghĩa thống kê với p>0,05

Bảng 3.2. Phân bốnhu cầu điêu trị theo số lần mang thai

\begin{tabular}{|c|c|c|c|c|c|c|c|c|}
\hline \multirow{2}{*}{$\begin{array}{l}\text { Mã số } \\
\text { thai mang }\end{array}$} & \multicolumn{2}{|c|}{ Mã số 0} & \multicolumn{2}{|c|}{ Mã số 1} & \multicolumn{2}{|c|}{ Mã số 2} & \multicolumn{2}{|c|}{ Mã số 3} \\
\hline & $\begin{array}{c}\text { Số } \\
\text { lươong }\end{array}$ & $\begin{array}{l}\text { Tỷ lệ } \\
(\%)\end{array}$ & $\begin{array}{c}\text { Số } \\
\text { Iượng }\end{array}$ & $\begin{array}{l}\text { Tỷ lệ } \\
(\%)\end{array}$ & $\begin{array}{c}\text { Số } \\
\text { Iượng }\end{array}$ & $\begin{array}{l}\text { Tỷ lệ } \\
(\%)\end{array}$ & $\begin{array}{c}\text { Số } \\
\text { Iượng }\end{array}$ & $\begin{array}{l}\text { Tỷ lệ } \\
(\%)\end{array}$ \\
\hline Lần 1 & 2 & 1,8 & 4 & 3,6 & 29 & 26,4 & 6 & 5,5 \\
\hline Lân 2 & 0 & 0,0 & 4 & 3,6 & 42 & 38,2 & 2 & 1,8 \\
\hline$>2$ lần & 0 & 0,0 & 1 & 0,9 & 19 & 17,3 & 1 & 0,9 \\
\hline Tống & 2 & 1,8 & 9 & 8,2 & 90 & 81,8 & 9 & 8,2 \\
\hline
\end{tabular}

Nhận xét: Nhu cầu điều trị mã số 2 chiếm tỷ lệ cao nhất và chủ yếu. Nhóm phụ nữ mang thai lần 1 có đủ̉ 4 mức nhu cầu điều trị 0-3. Nhóm phụ nữ mang thai lần 2 và trên 2 lần không có nhu cầu điều trị mã số 0 . Tuy nhiên, sự khác biệt giữa các nhóm không có ý nghĩa thống kê với p>0,05.

Bảng 3.3. Phân bố nhu cầu điều trị theo tuổi thai

\begin{tabular}{|c|c|c|c|c|c|c|c|c|}
\hline \multirow{2}{*}{ Tuổi thai } & \multicolumn{2}{|c|}{ Mã số 0} & \multicolumn{2}{|c|}{ Mã số 1} & \multicolumn{2}{|c|}{ Mã số 2} & \multicolumn{2}{|c|}{ Mã số 3} \\
\hline & $\begin{array}{c}\text { Số } \\
\text { Iượng }\end{array}$ & $\begin{array}{l}\text { Tỷ lề } \\
(\%)\end{array}$ & $\begin{array}{c}\text { Số } \\
\text { lượng }\end{array}$ & $\begin{array}{l}\text { Tỷ lệ } \\
\text { (\%) }\end{array}$ & $\begin{array}{c}\text { Số } \\
\text { lươơng }\end{array}$ & $\begin{array}{l}\text { Tỷ lệ } \\
(\%)\end{array}$ & $\begin{array}{c}\text { Số } \\
\text { Iượng }\end{array}$ & $\begin{array}{l}\text { Tỷ lệ } \\
(\%)\end{array}$ \\
\hline$<3$ Tháng & 2 & 1,8 & 9 & 8,2 & 9 & 8,2 & 0 & 0 \\
\hline 3-6 Tháng & 0 & 0,0 & 0 & 0 & 45 & 40,9 & 3 & 2,7 \\
\hline > 6 Tháng & 0 & 0,0 & 0 & 0 & 36 & 32,7 & 6 & 5,45 \\
\hline
\end{tabular}




\begin{tabular}{l|l|l|l|l|l|l|l|l} 
Tổng & 2 & 1,8 & 9 & 8,2 & 90 & 81,8 & 9 & 8,2
\end{tabular}

Nhận xét: Nhóm phụ nữ mang thai có tuối thai $<3$ tháng có nhu cầu điều trị từ mức đô $0-2$, không có mức độ 3. Nhóm phụ nữ mang thai có tuổi thai 3-6 tháng và $>6$ tháng chỉ có nhu cầu điêu trị mã số 2 và 3 . Sự khác biệt giữa các nhóm có ý nghĩa thống kê với $p<0,05$.

Bảng 3.4. Phần bốnhu cầu điều trị theo nhóm răng

\begin{tabular}{|c|c|c|c|c|c|c|c|c|}
\hline \multirow[t]{2}{*}{ |ã số } & \multicolumn{2}{|c|}{ Mã số 0} & \multicolumn{2}{|c|}{ Mã số 1} & \multicolumn{2}{|c|}{ Mã số 2} & \multicolumn{2}{|c|}{ Mã số 3} \\
\hline & $\begin{array}{c}\text { Số } \\
\text { lương }\end{array}$ & $\begin{array}{l}\text { Tỷ lệ } \\
(\%)\end{array}$ & $\begin{array}{c}\text { Số } \\
\text { lướng }\end{array}$ & $\begin{array}{l}\text { Tỷ lệ } \\
(\%)\end{array}$ & $\begin{array}{c}\text { Số } \\
\text { lương }\end{array}$ & $\begin{array}{l}\text { Tỷ lệ } \\
(\%)\end{array}$ & $\begin{array}{c}\text { Số } \\
\text { Iương }\end{array}$ & $\begin{array}{l}\text { Tỷ lệ } \\
(\%)\end{array}$ \\
\hline $\mathrm{Nh}$ & 2 & 1,8 & 27 & 24,6 & 80 & 72,7 & 1 & 0,9 \\
\hline Nhóm răng phía sau & 2 & 1,8 & 9 & 8,2 & 90 & 81,8 & 9 & 9,2 \\
\hline
\end{tabular}

Nhân xét: Nhóm răng phía trước chủ yếu có TN mã số 2 với tỉ lệ $72,7 \%$, tiếp theo là mã số 1 với tỉ lệ $24,6 \%$, mã số 3 có tỷ lệ thấp nhất $(0,09 \%)$. Nhóm răng phía sau chủ yếu có TN mã số 2 với tỉ lệ $81,8 \%$, tiếp theo là mã số 3 với tỉ lệ $9,2 \%$, mã số 0 có tỷ lệ thấp nhất $(1,8 \%)$. Sự khác biệt tỷ lệ mã̉ số giữa hai nhóm có ý nghĩa thống kê với $p<0,01$.

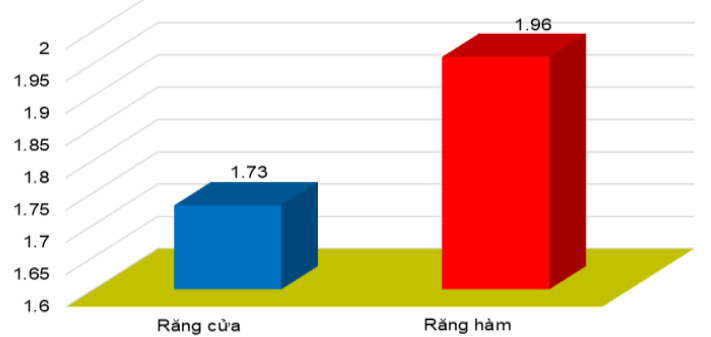

Biểu đồ 3.1. Chỉ sốnhu cầu điều trị theo nhóm răng

Nhân xét: Nhóm răng cửa có nhu cầu điều trị thấp hơn nhóm răng hàm, sự khác biệt giữa 2 nhóm có ý nghĩa thống kê với $p<0,001$.

\section{BÀN LUẦN}

Trong nghiên cứu này, chúng tôi nhận thẫy không có sự khác biệt rõ ràng về nhu cầu điều trị giữa các nhóm tuổi. Tuy nhiên, ở nhóm tuổi 30-39 và trên 40 tuổi không có nhu cầu điều trị ở mã số 0 và 1 , đồng thời nhóm tuổi $30-39$ có tỳ lệ mã số 3 cao hơn so với nhóm 20-29 tuổi (Bảng 3.1). Điều này cho thây khi tuổi tác tăng lên, nguy cơ tích tụ mảng bám và cao răng tăng lên, dẩn đến tình trạng bệnh nha chu tăng nặng hơn. Nghiên cứu của Wandera MN (2009) trên 877 phụ nữ mang thai tại Uganda[3], của Maybodi RF (2015) trên 115 phụ nữ mang thai tại Iran [4] cũng cho kết quả tương tự.

Phân tích nhu cầu điều trị theo số lần mang thai cũng cho thấy giữa các nhóm không có sự khác biệt về chỉ số nhu cầu điều trị, tuy nhiên ở nhóm phụ nữ mang thai lần 1 có chỉ số nhu cầu điêu trị mã số 3 chiếm $5,5 \%$ cao hơn hẳn so với nhóm mang thai 2 lần và trên 2 lần $(1,8 \%$ và $0,9 \%$ ) (Bảng 3.2). Điều này có thể do khi mang thai lần đầu, thai phụ chưa kịp thích nghi cũng như có chế độ sinh hoạt ăn uống phù hợp nên tình trang bệnh nha chu trầm trọng hơn so với những thai phụ mang thai nhiều lần.

Theo tuổi thai, kết quả nghiên cứu tại bảng 3.3 cho thấy, ở nhóm phụ nữ mang thai có tuổi thai <3 tháng, nhu cầu điều trị mã số 2 và mã số 1 bằng nhau $(8,2 \%)$ và mã số 0 là $1,8 \%$. Trong khi đó ở phụ nữ mang thai có tuổi thai 3-6 tháng và $>6$ tháng không có ai có nhu câuu điêu trị mã số 0 và 1 , tỷ lê lớn tập trung ở mã số 2 $(40,9 \%$ và $32,7 \%)$, mã số 3 ở phụ nữ mang thai 3 tháng cuối tăng gấp đôi so với nhóm 3-6 tháng $(5,5 \%$ và $2,7 \%)$. Nghiên cứu của Maybodi RF cho thấy tỷ lệ nhu cầu điều trị mã số 1 giữa các nhóm lần lượt là $25,5 \%$; $23 \%$ và $19,4 \%$; trong khi tỷ lệ nhu câu điêuu trị mã số 2 giữa các nhóm là $13,8 \% ; 19,8 \%$ và $32,4 \%$. Qua đó cho thây nhu cầu điều trị của phụ nữ mang thai ở giai đoan 3 tháng cuối của thai kì cao hơn hẳn so với giai đoạn 3 tháng giữa và 3 tháng đầu [4]. Yalcin F (2002) quan sát thấy có sự gia tăng đáng kể chỉ số GI, PI và chiều sâu thẳm khám ở phụ nữ mang thai giữa quý 1 và quý 3 của thai kỳ [5]. Nghiên cứu của Tezel A (2011) tại Thổ Nhĩ Kỳ cũng cho kết quả tương tự [6].

Phân tích nhu câu điều trị theo nhóm răng, biểu đồ 3.1 cho thấy nhu cầu điều trị của nhóm răng phía sau cao hơn nhóm răng phía trước. Kết quả này phù hợp với nghiên cứu của Loe và Silness (1963) khi cho rằng nhóm răng sau có độ sâu thăm khám cao hơn so với nhóm răng phía trước trong khi nhóm răng trước có sự gia tăng chỉ số GI cao hơn. Một yếu tố làm tăng nặng độ sâu thăm khám của nhóm răng sau là do cao răng, mảng bám tích tụ ở vùng răng sau khó vê sinh và làm sạch hơn so với nhóm răng phía trước [7].

\section{KẾT LUÂNN}

Trong nghiên cứu này, phụ nữ mang thai chủ yếu có nhu cầu điều trị viêm lợi mã số 2 . Nhu 
câu điều trị tăng dần theo tuổi thai và nhu câu ở nhóm răng phía trước thấp hơn so với nhóm răng phía sau. Cần tăng cường công tác chăm sóc sức khoẻ răng miệng cho phụ nữ có thai để kiểm soát bênh lý và loại bỏ các nguy cơ gây bệnh răng miệng tiềm ẩn có thể phát sinh trong suốt thai kỳ.

\section{TÀI LIÊU THAM KHẢO}

1. Offenbacher $S$, et al (1998). Potential pathogenic mechanisms of periodontitis-associated pregnancy complications. Ann Periodontol. 3(1):233-250

2. Marta Silveira da Mota Krüger, Renata Picanço Casarin, et al (2017). Periodontal Health Status and Associated Factors: Findings of a Prenatal Oral Health Program in South Brazil. International Journal of Dentistry. 2017:3534048.

3. Margaret N Wandera, Ingunn M.Engebretsen, et al (2009). Periodontal status, tooth loss and self-reported periodontal problems effects on oral impacts on daily performances, OIDP, in pregnant women in Uganda: a cross-sectional study. Health and Quality of Life Outcomes. 7(1):89.

4. Rashidi Maybodi $F$, Haerian-Ardakani $A$, et al (2015). CPITN changes during pregnancy and maternal demographic factors 'impact on periodontal health. Iran J Reprod Med. 13(2):107112.

5. Yalcin F, Eskinazi E, Soydinc M, Basegmez C Issever H, Isik G, et al (2002). The effect of sociocultural status on periodontal conditions in pregnancy. J Periodontol. 73(2):178-182

6. Tezel A (2011). Periodontal condition of pregnant women assessed by CPITN and the role of nurses according to the needs of treatment. Health Med. 5(6):1951-1955.

7. John Silness, Harald Löe (1964). Periodontal Disease in Pregnancy II. Correlation Between Oral Hygiene and Periodontal Condition. Acta Odontologica Scandinavica, 22(1):121-135.

\section{ĐÁNH GIÁ HIỆU QUẢ CHUYỂN ĐỔI HUYẾT THANH CỦA TENOFOVIR DISOPROXIL FUMARATE VÀ TENOFOVIR ALAFENAMIDE Ở BỆNH NHÂN VIÊM GAN VI RÚT B MẠN}

\section{TÓM TẮT}

Mục tiêu: Đánh giá hiệu quả chuyển đổi huyết thanh của Tenofovir disoproxil fumarate (TDF) và Tenofovir alafenamide (TAF) ở bệnh nhân viêm gan vi rút $B$ man. Đối tương và phương pháp: Nghiên cứu cắt ngang mô tả tiến hành trên 111 bệnh nhân viêm gan vi rút $\mathrm{B}$ man $\mathrm{HBeAg}$ dương tính điểu tri ngoai trú với TDF 300mg (74 bệnh nhân) hoặc TAF 25mg (37 bênh nhân) tai Bênh viện Đai hoc Y Dược TP HCM từ tháng 1/2017 đến tháng 12/2020. Kết quả: Trong cả 2 nhóm BN điều trị TAF hoăc TDF: tỉ lê nam giới đều chiếm ưu thế $(2,7 / 1)$; độ tuổi trung bình lần lượt là 41 và 37; chỉ số $A L T$ trung bình là $27 \mathrm{UI} / \mathrm{L}$ và $48 \mathrm{UI} / \mathrm{L}$; tải lượng HBV DNA trung bình tai thời điểm bắt đâu điều trị lần lượt là 7,85 và $7,87 \log _{10} \mathrm{UI} / \mathrm{ml}$. Sau 48 tuần điều tri, tỉ lê mất $\mathrm{HBeAg}$ của 2 nhóm lần lướt là $13,51 \%$ và $14,86 \%(p=0,84)$; tỉ lê đạt HBV DNA âm tính của nhóm BN điều trị TAF là $67,00 \%$ so với nhóm điều trị TDF là $58,10 \%$, với $p=0,33$; tỉ lệ đạt $A L T$ bình thường của 2 nhóm lần lượt là $54,54 \%$ và $33,33 \%$, $p=0,20$. Kết luận: Kết quả nghiên cứu cho thấy sau 48 tuần, hiệu quả điều trị tương đương nhau giữa 2

${ }^{1}$ Đại học Y Dược Thành phố Hồ Chí Minh Bềnh viện Chớ Rẫy, Thành phố Hồ Chí Minh Chịu trách nhiệm chính: Võ Duy Thông Email: duythong@ump.edu.vn

Ngày nhân bài: 3.2.2021

Ngày phản biên khoa họ: 22.3.2021

Ngày duyệt bài: 30.3.2021

\section{Võ Duy Thông',2, Võ Ngọc Diễm ${ }^{1}$}

nhóm BN điều trị TAF hoặc TDF về tỉ lê đạt tải lượng HBV DNA âm tính. Có sư khác biêt khổng có ý nghĩa thống kê giữa 2 nhóm điều trị TAF hoặc TDF về tỉ lệ mất $\mathrm{HBeAg}$, tỉ lệ đạt $\mathrm{ALT}$ bình thường.

Tư khóa: TAF, TDF, mất HBeAg, viêm gan vi rút $B$ mạn.

\section{SUMMARY}

EFFECT OF TENOFOVIR DISOPROXIL FUMARATE AND TENOFOVIR ALAFENAMIDE IN SEROCONVERSION IN PATIENTS WITH CHRONIC HEPATITIS B VIRUS

Objective: To evaluate the seroconversion efficacy of Tenofovir disoproxil fumarate (TDF) and Tenofovir alafenamide (TAF) in patients with chronic viral hepatitis B. Methods: A descriptive crosssectional study was conducted in 111 chronic hepatitis B outpatients with positive HbeAg treated with TDF $300 \mathrm{mg}$ (74 patients) or TAF $25 \mathrm{mg}$ (37 patients) at the Ho Chi Minh City University Medical Center from January 2017 to December 2020. Results: In both groups of patients treated with TAF or TDF, the percentage of men was dominant (2.7/1); the mean age in the two groups was 41 and 37 years old, respectively; Mean ALTs were 27 UI / L and 48 UI / Li mean HBV DNA load at initiation of treatment was 7.85 and $7.87 \log _{10} \mathrm{UI} / \mathrm{ml}$, respectively. After 48 weeks of treatment, the rate of HBeAg loss of the 2 groups were $13.51 \%$ and $14.86 \%$, respectively $(p=$ $0.84)$; The rate of HBV DNA negative in the group of 